\title{
Livestock-based knowledge of rangeland quality assessment and monitoring at landscape level among borana herders of northern Kenya
}

\author{
Bulle Hallo Dabasso ${ }^{*}$, Gufu Oba ${ }^{2}$ and Hassan G Roba ${ }^{3}$
}

\author{
* Correspondence: bulledabasso@ \\ yahoo.com \\ ${ }^{1}$ Kenya Agricultural Research \\ Institute, P.O. Box 147, Marsabit, \\ Kenya \\ Full list of author information is \\ available at the end of the article
}

\begin{abstract}
It has not been easy to capture landscape level grazing parameters through participatory assessment and monitoring of rangeland quality. Disagreements exist on what indicators to use and how the generated data can be linked to management-related information and whether the methods can be replicated across different grazing areas. Rangeland quality assessment and monitoring has hence focused on conventional scientific methods while the role of indigenous ecological knowledge of local herders has been given less emphasis. This study explored Borana herders' knowledge of assessing and monitoring rangeland quality at landscape level in Marsabit Central District in northern Kenya. A number of participatory methods have been used, including focused group discussion, key informant interviews and a joint field survey. We established that Borana herders have a considerable ecological knowledge which focuses on livestock-based indicators at the level of classified landscapes. The herders' personal experiences and social memory further provided an environmental history of grazing landscapes and their perceptions of rangeland quality change. The herders' knowledge can be integrated with conventional ecological methods to assess and monitor rangeland quality.

Keywords: Rangeland quality, Assessment and monitoring, Landscape, Indigenous knowledge, Marsabit
\end{abstract}

\section{Background}

Changes in range quality in terms of loss of vegetation diversity and cover have continued to attract research in the African communal rangelands (Vetter et al. 2006). The change has often been associated with intensive livestock grazing (Darkoh 2002; Rodriguez 2003; Bowman 2002) and shifts in land use from livestock grazing to crop farming and settlements. The latter not only reduces vegetation cover and diversity but also disrupts seasonal livestock movement necessary for opportunistic exploitation of spatially and temporally distributed rangeland resources (Byakagaba 2005).

The assessment and monitoring of the changes in rangeland quality with the objective of capturing landscape level dynamics has not been successful using conventional scientific methods alone. This is simply because the methods are not participatory and excludes perceptions and experiences of local herders who have detailed knowledge of changes in fodder plants at landscape scale (Roba and Oba 2009a). We argue that participatory rangeland 
quality assessment and monitoring, integrating indigenous ecological knowledge of local resource users with conventional scientific approaches, is a most appropriate method. Assessing and monitoring rangeland quality has been constrained by a lack of understanding of appropriate indicators used by pastoral herders (Yoccoz et al. 2001) and the perception that the knowledge is locally specific, qualitative and lacks impartiality (Oba and Kaitira 2006). However, pastoral herders have been known to have considerable knowledge of rangeland quality (Peden 2005; Mauro and Hardison 2000; Berkes 1999). Herders use assessment and monitoring indicators based on landscape level processes (Mapinduzi et al. 2003; Fernandez-Gimenez 2000; Oba et al. 2000).

Herders' assessments and monitoring of rangeland quality at landscape level considers ecological variability (Niamir-Fuller and Turner 1999; Scoones 1999) which reflects spatial and temporal variation in the distribution and productivity of indigenous vegetation (Scholes and Archer 1997; Boeken and Shachak 1994; Byakagaba 2005). The ecological variability, which is described by herders mainly in terms of micro-climate, soils, and topography, generally forms the basis of their landscape classification for landscape level rangeland quality assessment and monitoring (Oba and Kaitira 2006).

Pastoral herders' landscape level knowledge of rangeland quality is built upon their observations of relationships between vegetation and livestock (Bollig and Schulte 1999; Reed and Dougill 2002). Desirable forage plant species which are normally palatable to livestock are usually used by herders as indicators of favourable rangeland quality, while undesirable plants indicate degradation (Mapinduzi et al. 2003). Herders recognise all the desirable and undesirable plant species by local names (Gemedo-Dalle et al. 2005) and they monitor changes in their plant species composition over time, based on historical knowledge (Oba and Kaitira 2006). Low livestock productivity is attributed by herders to changes in rangeland vegetation composition from desirable to undesirable forage plants, which they assess and monitor at landscape level. Herders associate each grazing landscape with particular fodder species.

The knowledge of rangeland assessment and monitoring among Borana herders of northern Kenya is less well known. This study aims at evaluating Borana herders' knowledge of rangeland quality assessment and monitoring, based on their perceptions and experiences. Three research questions were posed:

a) How do Borana herders classify grazing landscapes?

b) How do Borana reconstruct environmental history of gazing landscapes? and

c) What indicators are used by Borana herders to assess and monitor landscape level vegetation changes?

\section{Methods}

The study was conducted in the Central Division of Marsabit Central District, Kenya, located between $01^{\circ} 15^{\prime}$ North and $04^{\circ} 27^{\prime}$ North and longitudes $36^{\circ} 03^{\prime}$ East and $38^{\circ} 59^{\prime}$ East (Warui and Nduma 2001). The study site is located along a topographical gradient from the highlands of Mount Marsabit towards the transitional zone between the mountain landscapes and arid plains, 5-6 km out of Marsabit town in a north westerly direction. The site stretches from an elevation of about $1300 \mathrm{~m}$ above sea level in the upper part of Mount Marsabit and slopes gently into open woodland or savannah at the foot of the mountain to 
an estimated elevation of $800 \mathrm{~m}$ above sea level. Annually rainfall ranges from 500 to $1000 \mathrm{~mm}$ and is distributed bio-modally between March-April and October-December (Bulle et al. 2010).

The area is inhabited by diverse ethnic groups including Borana, Rendille Gabra and Burji. Agro-pastoralism is the dominant livelihood where livestock such as cattle, goats, donkeys and camels are kept in a semi-sedentary pastoral system combined with crop cultivation in the humid zone of Mount Marsabit. Farming is rain-fed with common crops including maize, beans, wheat, sorghum, millet, teff and cowpeas grown on a small scale mainly for subsistence. Semi-sedentary pastoralism coupled with the reduction of grazing areas by encroachment of farming and settlement areas have created pressure on rangeland vegetation, leading to deterioration in some areas (Shibia 2010).

Focus group discussions on indigenous knowledge of rangeland quality assessment and monitoring were held with 12 key herders selected from different villages. Discussions were guided by open-ended questions. The researchers asked questions regarding knowledge of landscape characterisation, concepts of landscape assessment and monitoring, and perceptions of change in landscape quality, with sufficient time given for the responses. Discussions were followed by selection of knowledgeable herders who were asked to survey range areas jointly with the research ecologists, using the discussed concepts. The criteria used to select herders were age and experience of livestock herding in the study area. During the survey, landscape units were identified and described, using traditional indicators provided by herders.

The environmental histories of the assessed landscapes were established using key informants' knowledge. In-depth, semi-structured interviews were held with ten key informants on their knowledge of environmental history of the grazing landscapes and their perceptions of rangeland quality change. All the key informants interviewed were elders who were either born or had lived in the study area for over 30 years and were therefore knowledgeable about environmental changes.

Community historical events and traditional system of counting years were used to enable herders' recall of environmental changes. These were evaluated using social memory. Referring to the traditional Borana $g a d a^{a}$ system (Legesse 1973), key informants were requested to narrate environmental changes during certain period of the gada.

Representative areas of each landscape unit were then assessed for rangeland quality, using herders' indicators. To facilitate the quantification of forage plants which were used by the herders as one of the indicators for rangeland quality, nested plots $(1 \times 1 \mathrm{~m}$ for herbaceous species, $4 \times 4 \mathrm{~m}$ for shrubs and $10 \times 10 \mathrm{~m}$ for trees) were placed at 40 -m intervals along 240-m long-transects (Mapinduzi et al. 2003). Three to four transects were placed on each assessed landscape to cover a sufficient area. Herders identified forage plants and assessed livestock preference and availability trend of forage plants on each nested plot along transects. Forage plants were categorised as 'decreasing,' 'increasing' and 'stable, based on the availability trend over the years as perceived by herders.

\section{Analyses}

The herders' narratives were used to describe the knowledge of landscape classification and changes in rangeland quality. The historical environmental changes were qualitatively analysed from elders' narratives for common environmental phenomena. Plant frequency data 
were used to determine the composition of plant species preferred by cattle, camels and goats and their trend over the years at each landscape. The differences in the composition of 'decreasing,' 'increasing' and 'stable' forages on surveyed landscapes and their variations with livestock preference were analysed using Analysis of Variance and significance differences accepted at $P<0.05$.

\section{Results and discussion}

Herders categorised the study area into two macro landscapes, namely, Badhaa and Gamoji, which had contrasting microclimates. The Badhaa macro landscape represents the cool sub-humid uplands, characterised by red volcanic soil and high tree canopy cover. The Gamoji represents the warm lowlands, with dark to grey soils and covered mainly with lower scrub vegetation. The two macro landscapes are used in different seasons and allow spatial distribution of grazing pressure. Badhaa is used as dry season grazing while Gamoji is used for wet season grazing. The macro landscapes were further divided into micro landscapes based upon diverse environmental indicators such as topography, soil and dominant vegetation (Table 1). The naming of micro landscapes reflected the criteria used in classification and availability of daily grazing resources.

Table 1 Description and classification criteria of micro landscapes

\begin{tabular}{|c|c|c|}
\hline Landscape name & Description & Classification criteria \\
\hline Gar fonqocha & $\begin{array}{l}\text { Hilly topography surrounded by } \\
\text { farms and settlements. Mostly } \\
\text { used reserved as calf and weak } \\
\text { animals pasture (kallo). The soil is } \\
\text { dominantly sandy loam. Mostly } \\
\text { covered with shrub vegetation } \\
\text { predominate by Maytenus sp. }\end{array}$ & $\begin{array}{l}\text { Topography and dominate } \\
\text { vegetation }\end{array}$ \\
\hline Diid ogono & $\begin{array}{l}\text { Open grassland with discontinuous } \\
\text { patches of farms. Sometimes used } \\
\text { as private enclosures (kallo). } \\
\text { Mostly covered with grass } \\
\text { vegetation dominated by } \\
\text { Pennisetum mezianum (Heim.) }\end{array}$ & $\begin{array}{l}\text { Topography and dominate } \\
\text { vegetation }\end{array}$ \\
\hline Qaa wachu & $\begin{array}{l}\text { Riverine dominated by Acacia } \\
\text { seya (Del.) The soil is sandy loam } \\
\text { with moderate drainage. } \\
\text { Vegetation cover increases } \\
\text { towards the valley bottom }\end{array}$ & Topography and vegetation \\
\hline Kootich ammessa & $\begin{array}{l}\text { Bush land dominated by } \\
\text { Commiphora Africana (A.Rich). } \\
\text { The soil is poorly drained black } \\
\text { clay, sticky when wet and cracks } \\
\text { when dry. Mostly suited for goats } \\
\text { and camel due to high cover of } \\
\text { desirable trees and shrubs species }\end{array}$ & Soil and vegetation \\
\hline Kootich sapansa & $\begin{array}{l}\text { Bush land dominated by Acacia } \\
\text { mellifera (Benth). The soil is } \\
\text { poorly drained black clay soil }\end{array}$ & Soil and vegetation \\
\hline Kootich fullessa & $\begin{array}{l}\text { Shrub land scattered with Acacia } \\
\text { drepanolobium (Sjoestedt). Flat } \\
\text { plateau with poorly drained black } \\
\text { clay soil }\end{array}$ & Soil and vegetation \\
\hline
\end{tabular}


A historical timeline of the traditional gada system was used to capture historical environment changes that relate to vegetation. Key informants were able to remember the major environment changes using the gada periods and narrated the changes at macro landscape scale. The two macro landscape units of Badha and Gamoji therefore formed the basic unit for environment narration (Table 2).

Table 2 Environmental history of Badha and Gamoji landscapes of Marsabit central

\begin{tabular}{|c|c|c|c|}
\hline \multirow[t]{2}{*}{ Gada period } & \multirow{2}{*}{$\begin{array}{l}\text { Conventional } \\
\text { period }\end{array}$} & \multicolumn{2}{|l|}{ Landscape environmental history } \\
\hline & & Badha & Gamoji \\
\hline $\begin{array}{l}\text { Guyo Goba } \\
\text { Bulle }\end{array}$ & $\begin{array}{l}2010 \text { to date } \\
\text { (2011) }\end{array}$ & $\begin{array}{l}\text { Shifting to camel keeping and } \\
\text { miraa (khat) farming continued }\end{array}$ & $\begin{array}{l}\text { Loss of livestock productivity, } \\
\text { invasive plant species, charcoal } \\
\text { burning and exploitation of woody } \\
\text { species increased }\end{array}$ \\
\hline \multirow[t]{3}{*}{$\begin{array}{l}\text { Liban Jaldesa } \\
\text { Liban }\end{array}$} & \multirow[t]{3}{*}{ 2002-2009 } & \multirow[t]{3}{*}{$\begin{array}{l}\text { Some pastoralists start shifting } \\
\text { to camel keeping as strategy to } \\
\text { drought and also take up } \\
\text { opportunity of increasing milk } \\
\text { demand for settled population. } \\
\text { Miraa (khat) farming further } \\
\text { intensified and most farmers } \\
\text { abandoned the traditional crops }\end{array}$} & $\begin{array}{l}\text { Productivity of the landscape for } \\
\text { perennial grasses and other forage } \\
\text { plants declined while invasive } \\
\text { plants species such as D. eremophilum } \\
\text { and A. mossambicensis } \\
\text { were seen to be increasing while } \\
\text { preferred grasses declined. }\end{array}$ \\
\hline & & & $\begin{array}{l}\text { Commercial exploitation of woody } \\
\text { plant species such as Terminalia sp. } \\
\text { for construction started in } \\
\text { addition to charcoal burning. }\end{array}$ \\
\hline & & & $\begin{array}{l}\text { Livestock milk production was } \\
\text { noted to be on decline even during } \\
\text { wet season, the concept elders } \\
\text { refers to as Horrin damma dabee }\end{array}$ \\
\hline \multirow[t]{2}{*}{$\begin{array}{l}\text { Boru Madha } \\
\text { Galma }\end{array}$} & \multirow[t]{2}{*}{ 1994-2001 } & \multirow{2}{*}{$\begin{array}{l}\text { Droughts occurrence becomes } \\
\text { frequent and crop failures were } \\
\text { experienced quite often. Few } \\
\text { farmers started shifting to } \\
\text { miraa farming. } \\
\text { El nino rains eroded soil } \\
\text { conservation structures on the } \\
\text { farms and soil erosion } \\
\text { contributed to a decline in crop } \\
\text { production }\end{array}$} & $\begin{array}{l}\text { Charcoal burning continued } \\
\text { targeting ecologically important } \\
\text { tree species such as Acacia } \\
\text { species. }\end{array}$ \\
\hline & & & $\begin{array}{l}\text { Overgrazing observed and } \\
\text { livestock preferred grass species } \\
\text { such as C. ciliaris and C. plumulosus } \\
\text { declined }\end{array}$ \\
\hline $\begin{array}{l}\text { Boru Guyo } \\
\text { Boru }\end{array}$ & 1986-1993 & $\begin{array}{l}\text { A major drought called the } \\
\text { drought of yellow maize (Olla } \\
\text { dima suggah) occurred. } \\
\text { Pastoralists lost animals and } \\
\text { settled to engage in farming } \\
\text { and other livelihood strategies. } \\
\text { The grazing areas continue to } \\
\text { be reduced }\end{array}$ & $\begin{array}{l}\text { The settled destitute pastoralists in } \\
\text { the Badha landscape started } \\
\text { charcoal burning activities in } \\
\text { Gamoji landscape }\end{array}$ \\
\hline Jillo Aga Adi & 1978-1985 & $\begin{array}{l}\text { A major drought traditionally } \\
\text { called Oola Athu thoote (the } \\
\text { drought of solar eclipse) } \\
\text { occurred and most pastoralists } \\
\text { lost their animals and became } \\
\text { destitute. Catholic mission } \\
\text { initiated settlement schemes to } \\
\text { settle pastoral drop outs. } \\
\text { Several settlement schemes } \\
\text { such as Manyatta Jillo } \\
\text { settlement scheme, Gabra } \\
\text { settlement scheme and Badassa } \\
\text { refuge scheme were } \\
\text { established. The settlement } \\
\text { schemes took up large } \\
\text { proportion of grazing lands }\end{array}$ & $\begin{array}{l}\text { A major drought of solar eclipse } \\
\text { coupled with increasing number of } \\
\text { livestock reduced the productivity } \\
\text { of the Gamoji Landscapes and } \\
\text { several nomadic families lost their } \\
\text { animals and decided to settle in the } \\
\text { Badha Landscape }\end{array}$ \\
\hline
\end{tabular}


Table 2 Environmental history of Badha and Gamoji landscapes of Marsabit central (Continued)

\begin{tabular}{|c|c|c|c|}
\hline $\begin{array}{l}\text { Goba Bulle } \\
\text { Dabasso }\end{array}$ & 1970-1977 & $\begin{array}{l}\text { The farming and settlements } \\
\text { slowly took up grazing areas in } \\
\text { the Badha landscape }\end{array}$ & $\begin{array}{l}\text { Livestock number increased and } \\
\text { continuously grazed the landscape } \\
\text { as the Badha landscapes were } \\
\text { increasingly put under farming } \\
\text { and settlements }\end{array}$ \\
\hline $\begin{array}{l}\text { Jaldesa Liban } \\
\text { Guyo }\end{array}$ & 1962-1969 & $\begin{array}{l}\text { The farming and settlements } \\
\text { slowly took up grazing areas in } \\
\text { the Badha landscape }\end{array}$ & $\begin{array}{l}\text { Evidence of overgrazing in } \\
\text { some areas }\end{array}$ \\
\hline $\begin{array}{l}\text { Madha Galma } \\
\text { Tore }\end{array}$ & 1954-1961 & $\begin{array}{l}\text { Colonial government issued } \\
\text { directive to reduce livestock } \\
\text { number on the Badha } \\
\text { landscape as farming and } \\
\text { settlements increase. } \\
\text { Pastoralists were encouraged } \\
\text { to keep few animals. Each } \\
\text { pastoral household was } \\
\text { allowed to keep } 12 \text { animals (8 } \\
\text { cows, } 2 \text { oxen, } 2 \text { sheep or } \\
\text { goats). The rest of the animals } \\
\text { were taken to the Gamoji } \\
\text { landscape. The measure was } \\
\text { taken to control overgrazing } \\
\text { and conserve the environment }\end{array}$ & $\begin{array}{l}\text { The grazing control instituted by } \\
\text { colonial government on the Badha } \\
\text { landscapes increased the number } \\
\text { of livestock in the Gamoji } \\
\text { Landscapes. This was the } \\
\text { beginning of major land use } \\
\text { change }\end{array}$ \\
\hline $\begin{array}{l}\text { Guyo Boru } \\
\text { Galma }\end{array}$ & 1946-1953 & $\begin{array}{l}\text { Plots and farms demarcation } \\
\text { by colonial government began } \\
\text { with increasing settlements and } \\
\text { farming activities }\end{array}$ & $\begin{array}{l}\text { The landscapes had sufficient } \\
\text { forages plants dominated by } \\
\text { preferred grasses such as C. ciliaris } \\
\text { and C. plumulosus }\end{array}$ \\
\hline $\begin{array}{l}\text { Aga Adi } \\
\text { Doyo }\end{array}$ & 1938-1945 & $\begin{array}{l}\text { Settlement and farming } \\
\text { activities increased on small } \\
\text { scale but large tract of land } \\
\text { with sufficient forages } \\
\text { remained for livestock grazing }\end{array}$ & $\begin{array}{l}\text { The landscapes were rich in } \\
\text { forages plants dominated by } \\
\text { preferred grasses such as C. ciliaris } \\
\text { and C. plumulosus }\end{array}$ \\
\hline $\begin{array}{l}\text { Bulle Dabassa } \\
\text { Bulle }\end{array}$ & 1930-1937 & $\begin{array}{l}\text { Minimal farming activities } \\
\text { started with influence of Burji } \\
\text { farmers and encouragement by } \\
\text { colonial government }\end{array}$ & $\begin{array}{l}\text { The landscape had adequate } \\
\text { forages plants dominated by } \\
\text { preferred grasses such C. ciliaris } \\
\text { and C. plumulosus }\end{array}$ \\
\hline $\begin{array}{l}\text { Arero Gedho } \\
\text { Liban }\end{array}$ & 1922-1929 & $\begin{array}{l}\text { The landscape continued to be } \\
\text { used for grazing }\end{array}$ & $\begin{array}{l}\text { The landscape had adequate } \\
\text { forages plants dominated by } \\
\text { preferred grasses such as C. ciliaris } \\
\text { and C. plumulosus }\end{array}$ \\
\hline $\begin{array}{l}\text { Liban Kuse } \\
\text { Liban }\end{array}$ & 1914-1921 & $\begin{array}{l}\text { The land is largely used for } \\
\text { grazing only. Few Burji } \\
\text { farmers were later brought } \\
\text { from Ethiopia by Colonial } \\
\text { government to encourage } \\
\text { farming }\end{array}$ & $\begin{array}{l}\text { The landscape had adequate } \\
\text { forages plants dominated by } \\
\text { preferred grasses such as C. ciliaris } \\
\text { and C. plumulosus }\end{array}$ \\
\hline
\end{tabular}

The informants reported that Badha landscape is historically used for dry season grazing and as a habitat for a large number of wild animals including elephants, Greater kudus, buffaloes, leopard, Grevy Zebras and Grant's gazelles. They indicated that the current farming and settlements areas of Badha landscape were covered with plenty of grasses. An elder recalled Badha vegetation during his childhood as follows:

There were tall grasses in most of the current farming or settlement areas which we use to play hide and seek game...., we sometimes used to spot buffaloes in those grasses.

The informants narrated that during the gada period of Aga Adi Doyo (1938-1946), only a few people settled on the Badha landscape and initiated small-scale crop cultivation. The informants further recalled that during that period, rainfalls were adequate 
and livestock milk production was higher. One informant summarised the livestock production and rainfall performance during those days as follows:

We were encouraged by colonial government to take up land and start farming, but we did not have any interest then because we had adequate number of animals which were producing enough milk. The few who started farming had also substantial harvests which sometimes rotted in the fields due to continuous rains.

The informants recalled the Gamoji landscape as grassland interspersed with woody plants, grazed mostly during wet season. They narrated that due to the invasion of farming and settlements in most grazing areas of the Badha landscape, livestock now are continuously grazed on the Gamoji landscape. An elder explained this situation further.

Our livestock these days trek to Badha landscape for watering purpose only and return immediately to constantly graze Gamoji landscapes since there is no land left for grazing on the Badha landscape. The few areas left are either enclosed or overgrazed.

The informants observed that continuous grazing had affected the vegetation of the Gamoji landscape and important forage plants had hence declined, while invasive plant species are spreading. One informant who is a herder from his childhood narrates We normally do not see a lot of Sarima (Duosperma eremophilum) and Aatha (Aspilia mossambicensis) in most of these areas but now they are everywhere and important cattle grasses such as Maatgudeesa (Cenchrus ciliaris) and Allaloo (Chrysopogon plumulosus) are hardly seen even during the rains,..... The invasive species are good for camels but even camels are now increasingly reared on Badha landscapes and feed on Anno (Euphorbia tirucalli) which were planted to fence farms.

The informants further narrated that the level of anthropogenic activities on the Gamoji landscapes such as charcoal burning and logging had increased and affected availability of forage plants. An 80-year-old informant explained this further

In the past, our community had no households involved in charcoal burning, but after the major drought that occurred in the gada period of Jillo Aga Adi (locally referred as the drought of solar eclipse which occurred in 1973), many pastoralists became destitute and were settled on schemes. The settled pastoralists started charcoal burning as a livelihood strategy. They cut down the trees which are important forage plants for goats and camels..... In recent years they have also started commercial logging of Qoroobbo (Terminalia sp.) for house construction and this species has nearly disappeared.

The changes had adversely affected the productivity performances of livestock.

From the herders' assessments, the availability of desirable forages indicates good rangeland quality while availability of undesirable forages indicates poor quality. The herders categorised forage plants into desirability classes (i.e. 'very desirable,' 'desirable,' 'partly desirable, 'undesirable') based on livestock preferences (Table 3). The 'very desirable' forages are highly selected by livestock and given preference during grazing. The livestock shift down the desirability scale (from very desirable to least desirable) as the range conditions deteriorate. During the dry season when the most desirable species were over-utilised, the livestock tended to be less selective in their feeding habits.

Herders were able to identify a total of 87 different plant species, and able to describe their preferences for different types of livestock as well as the trend for a 10-year period 
(Table 3). Based on the trend over the years, forages were categorised as 'decreasing, 'increasing' and 'stable'. The availability of 'decreasing, 'increasing' and 'stable' forage is significantly different in all landscapes $(F$-tests, all $P<0.05)$ except in Qaa wachu

Table 3 Livestock preferences and trend of plant species in surveyed landscapes of Marsabit Central District, Kenya

\begin{tabular}{|c|c|c|c|c|c|c|c|}
\hline \multirow{2}{*}{$\begin{array}{l}\text { Species } \\
\text { botanical } \\
\text { name }\end{array}$} & \multirow[t]{2}{*}{ Authority $^{\mathrm{a}}$} & \multirow{2}{*}{$\begin{array}{l}\text { Species } \\
\text { local } \\
\text { name } \\
\text { (Borana) }\end{array}$} & \multirow{2}{*}{$\begin{array}{l}\text { Life } \\
\text { form }\end{array}$} & \multirow[t]{2}{*}{ Trend } & \multicolumn{3}{|c|}{ Livestock preference } \\
\hline & & & & & Cattle & Goat & Camel \\
\hline Pennisetum mezianum & Heim & Ogoono & Herb & Decreasing & $\mathrm{D}$ & $P$ & $P$ \\
\hline Unidentified & & Lucholee & Herb & Decreasing & VD & $\mathrm{D}$ & $\mathrm{D}$ \\
\hline Rhus natalensis & Krauss & Thabobes & Shrub & Stable & $U$ & $\mathrm{D}$ & $\mathrm{D}$ \\
\hline Unidentified & & Itho & Herb & Decreasing & VD & $P$ & $\mathrm{P}$ \\
\hline Siege sp. & & Santu & Herb & Increasing & $\mathrm{D}$ & $\mathrm{D}$ & $P$ \\
\hline A. mossambicensis & (Olive.)Wild. & Atha & Shrub & Increasing & $P$ & VD & VD \\
\hline Maytenus sp. & & Fonqolch & Tree & Stable & U & $\mathrm{D}$ & $P$ \\
\hline C. ciliaris & $\mathrm{L}$. & Math gudes & Herb & Decreasing & VD & $\mathrm{D}$ & $\mathrm{D}$ \\
\hline Osyris abyssinca & A. Rich & Wato & Tree & Stable & U & VD & VD \\
\hline Aloe sp. & & Arges & Shrub & Decreasing & U & U & U \\
\hline Unidentified & & Gurbi olla & Herb & Decreasing & D & $\mathrm{D}$ & $\mathrm{D}$ \\
\hline Commelina africana & $\mathrm{L}$. & Qayo & Herb & Increasing & VD & $\mathrm{D}$ & $\mathrm{D}$ \\
\hline Unidentified & & Ubbe & Herb & Decreasing & $\mathrm{D}$ & $\mathrm{D}$ & $\mathrm{D}$ \\
\hline Solanum incanum & $\mathrm{L}$. & Iddi & Shrub & Increasing & U & $P$ & U \\
\hline Carris edulis & (Forsk.) Vahl & Dagams & Tree & Stable & U & $\mathrm{D}$ & $\mathrm{D}$ \\
\hline Sporobolus sp. & & Ilmogor & Herb & Decreasing & D & $\mathrm{D}$ & $\mathrm{D}$ \\
\hline Croton megalocarpus & Hutch. & Mokhof & Tree & Stable & $P$ & $P$ & $P$ \\
\hline Lantana sp. & & Midan thubra & Shrub & Decreasing & $\mathrm{D}$ & VD & VD \\
\hline Siege sp. & & Barchuma tite & Herb & Decreasing & VD & $\mathrm{D}$ & $\mathrm{D}$ \\
\hline Grewia bicolour & Juss. & Arrores & Tree & Decreasing & $P$ & $P$ & $P$ \\
\hline Hibiscus micranthus & L.F. Suppl. & Bungalla & Shrub & Decreasing & $D$ & $\mathrm{D}$ & $\mathrm{D}$ \\
\hline Phyllanthus somalensis & Hutchinson & Diri warseso & Shrub & Stable & $P$ & $\mathrm{D}$ & $\mathrm{D}$ \\
\hline Unidentified & & Jilibo & Herb & Stable & $\mathrm{D}$ & $\mathrm{D}$ & $\mathrm{D}$ \\
\hline Oropetium sp. & & Roba jires & Herb & Increasing & VD & $\mathrm{D}$ & $\mathrm{D}$ \\
\hline Aristida sp. & & Billa & Herb & Decreasing & VD & $\mathrm{D}$ & $\mathrm{D}$ \\
\hline Unidentified & & Challachalu & Shrub & Stable & $P$ & $\mathrm{D}$ & $\mathrm{D}$ \\
\hline Dichrostachys cinerea & $L$. & Jirimme & Shrub & Increasing & $P$ & VD & $\mathrm{D}$ \\
\hline Commiphora africana & A.Rich & Ammess & Tree & Stable & U & VD & VD \\
\hline Euclea schimperia & (DC.) Dandy & Miesa & Tree & Stable & U & $\mathrm{D}$ & D \\
\hline Pappea capensis & Sond.\&Harv. & Biqa & Tree & Decreasing & $\mathrm{D}$ & $\mathrm{D}$ & $\mathrm{D}$ \\
\hline Tribulus sp. & & Mogorre & Herb & Decreasing & $\mathrm{D}$ & $\mathrm{D}$ & $\mathrm{D}$ \\
\hline Blepharis sp. & & Barrat & Herb & Decreasing & $P$ & VD & VD \\
\hline Unidentified & & Dukubsa & Herb & Stable & $\mathrm{D}$ & $\mathrm{D}$ & $\mathrm{D}$ \\
\hline Olea Africana & Mill. & Ejers & Tree & Stable & $U$ & $U$ & U \\
\hline Acacia mellifera & Benth. & Sapans & Tree & Stable & U & $\mathrm{D}$ & $\mathrm{D}$ \\
\hline Balanites aegyptiaca & (L.) Del & Badan & Tree & Stable & U & $P$ & $P$ \\
\hline Unidentified & & Bisile & Herb & Stable & D & D & D \\
\hline
\end{tabular}


Table 3 Livestock preferences and trend of plant species in surveyed landscapes of Marsabit Central District, Kenya (Continued)

\begin{tabular}{|c|c|c|c|c|c|c|c|}
\hline Propelia sp. & & Haqarre & Herb & Decreasing & $P$ & $\mathrm{D}$ & $\mathrm{D}$ \\
\hline Cordia sinensis & Lam. & Madder & Shrub & Stable & D & $\mathrm{D}$ & D \\
\hline Unidentified & & Alallo & Herb & Decreasing & VD & $\mathrm{D}$ & D \\
\hline Solanum sp. & & Iddi watiti & Shrub & Increasing & $U$ & $P$ & U \\
\hline Commiphora sp. & & Challanga & Tree & Stable & U & VD & VD \\
\hline Asparagus sp. & & Okolle & Shrub & Stable & $P$ & $\mathrm{D}$ & $\mathrm{D}$ \\
\hline Grewia villosa & Wild. & Ogomdi & Shrub & Stable & $P$ & D & $\mathrm{D}$ \\
\hline Acacia tortillis & (Forsk.)Hayne & Dadacha & Tree & Stable & U & $\mathrm{D}$ & $\mathrm{D}$ \\
\hline Unidentified & & Chimpa & Herb & Decreasing & $\mathrm{D}$ & $\mathrm{D}$ & $\mathrm{D}$ \\
\hline Cadaba farinose & Forsk. & Dumaso & Shrub & Stable & $P$ & $\mathrm{D}$ & $\mathrm{D}$ \\
\hline Ormocarpum trichocarpum & (Taub.) Engl. & Butiye & Shrub & Stable & U & $\mathrm{D}$ & $P$ \\
\hline Acacia seyal & Del. & Wachu & Tree & Increasing & U & $\mathrm{D}$ & $\mathrm{D}$ \\
\hline Tagetes minuta & $\mathrm{L}$. & Halaku ajo & Herb & Stable & $P$ & D & $\mathrm{D}$ \\
\hline Ocimum hadiense & Forsk. F. I. & Urgo dada & Shrub & Decreasing & $P$ & $U$ & U \\
\hline Brachiaria sp. & & Bododi & Herb & increasing & $D$ & $\mathrm{D}$ & $\mathrm{D}$ \\
\hline Unidentified & & Tutufi & Herb & Stable & U & $U$ & $U$ \\
\hline Sansevieria abyssinica & N.E Br. & Chake & Shrub & Stable & $P$ & $P$ & $P$ \\
\hline Plectranthus igniarius & Schweinf. & Barbares & Shrub & Stable & $D$ & $\mathrm{D}$ & $\mathrm{D}$ \\
\hline Commiphora rivae & Engl. & Agarsu & Tree & Stable & U & VD & VD \\
\hline Acacia brevispica & Harms. & Hamares & Tree & Stable & U & VD & $\mathrm{D}$ \\
\hline Unidentified & & Mirtu & Herb & Decreasing & VD & $\mathrm{D}$ & $\mathrm{D}$ \\
\hline Acacia drepanolobium & Sjoestedt & Fulles & Tree & Decreasing & U & VD & $\mathrm{D}$ \\
\hline Duosperm eremophilu & (M.R) Napper & Sarim & Shrub & Increasing & $P$ & $\mathrm{D}$ & VD \\
\hline Acacia sp. & & Golole & Tree & Increasing & U & $\mathrm{D}$ & $\mathrm{D}$ \\
\hline Solanum sp. & & Iddi gaga & Shrub & Increasing & U & P & $P$ \\
\hline Lantana viburnoides & (Forssk.)Vahl & Qatte & Shrub & Stable & $U$ & D & VD \\
\hline Acacia senegal & (L.)Wild. & Idado & Tree & Increasing & $U$ & $\mathrm{D}$ & $\mathrm{D}$ \\
\hline Unidentified & & Rath waga & Herb & Stable & U & U & U \\
\hline Unidentified & & Rarri & Herb & Stable & $U$ & U & U \\
\hline Salvadora persica & $\mathrm{L}$. & Athee & Shrub & Stable & $U$ & $\mathrm{D}$ & D \\
\hline E. tirucalli & $L$. & Anno surre & Shrub & Increasing & $U$ & U & U \\
\hline Indigofera sp. & & Asura & Shrub & Decreasing & $D$ & VD & VD \\
\hline Eurphobia sp. & & Arsa & Herb & Stable & $U$ & $\mathrm{D}$ & $\mathrm{D}$ \\
\hline Indigofera schimperi & Jaub.\& Spach & Agargaro & Shrub & Stable & $U$ & D & $\mathrm{D}$ \\
\hline Asparagus sp. & & Ergems & Shrub & Stable & $U$ & $\mathrm{D}$ & $\mathrm{D}$ \\
\hline Justicia sp. & & Dukisa & Herb & Decreasing & $D$ & $\mathrm{D}$ & $\mathrm{D}$ \\
\hline Portulaca sp. & & Chuma iyessa & Herb & Increasing & D & $\mathrm{D}$ & $\mathrm{D}$ \\
\hline Cussonia holstii & Harms. & Abrata & Tree & Stable & $P$ & $\mathrm{D}$ & D \\
\hline Heliotropium sp. & & Digaji & Shrub & Increasing & $\mathrm{D}$ & VD & VD \\
\hline Barleria ecanthoides & Vahl & Qiltipe & Herb & Stable & $U$ & VD & VD \\
\hline Volkensinia prostrata & (Gilg) Schinz & Jilbete & Shrub & Stable & $D$ & VD & D \\
\hline Boswellia hilderbrandtii & Engl. & Thakar & Tree & Stable & $U$ & VD & $\mathrm{D}$ \\
\hline Coleus sp. & & Abune & Shrub & Stable & $U$ & $\mathrm{D}$ & D \\
\hline Unidentified & & Tititu & Shrub & Stable & $U$ & $\mathrm{D}$ & $\mathrm{D}$ \\
\hline
\end{tabular}


Table 3 Livestock preferences and trend of plant species in surveyed landscapes of Marsabit Central District, Kenya (Continued)

\begin{tabular}{llllllll}
\hline Unidentified & & Buyo haree & Herb & Stable & D & D & D \\
Lannea triphylla & A.Rich & Handarak & Tree & Stable & $U$ & D & P \\
Stegnanotaenia aralacea & Hostst. & Luqaluqe & Tree & Stable & $U$ & D & VD \\
Sterculia africana & (Louri).Fiori & Qarari & Tree & Stable & $U$ & $U$ & $U$ \\
Grewia tembensis & Fress. & Deka & Shrub Stable & P & D & D \\
Acacia reficiens & Wawra & Sigiriso & Tree & Stable & $U$ & D & D
\end{tabular}

VD, very desirable; $D$, desirable; $P$, partly desirable; $U$, undesirable.

${ }^{a}$ The name of scientist who first published the scientific name.

landscape $(P>0.05)$. In most landscapes, the proportion of 'stable' and 'increasing' forage species was relatively more, compared to the 'decreasing' and 'stable' forages species (Figure 1). The greater proportion of 'decreasing' species is preferred by cattle while 'increasing' species are preferred by goats and camels (Figure 2).

The herders' concept of rangeland quality was closely related to livestock productivity response. Livestock which graze on landscapes with high quality of forage resources are expected to increase milk production, exhibit good health, high mating frequency and more successful calving or kidding rates. The texture of animal dung and hair condition are also used by the herders to determine the quality of forages on different landscapes. Livestock grazed on good quality landscapes have smooth body hair but when grazed on poor quality landscapes they display rough body hair. Herders believe that livestock instinctively assessed the condition of the rangeland and adjust their behaviour accordingly. The livestock would refuse to graze on landscapes that have poor forage quality. The rangeland quality indicators are gauged from livestock productivity performance observed at landscape level. The quality varied from one landscape to another (Bollig and Schulte 1999; Oba 1985, 1994).

Using the livestock-based concept of environmental change, the Borana herders were able to monitor rangeland at landscape level over several years and related the current status to historical socio-economic events. They are able to show deteriorating

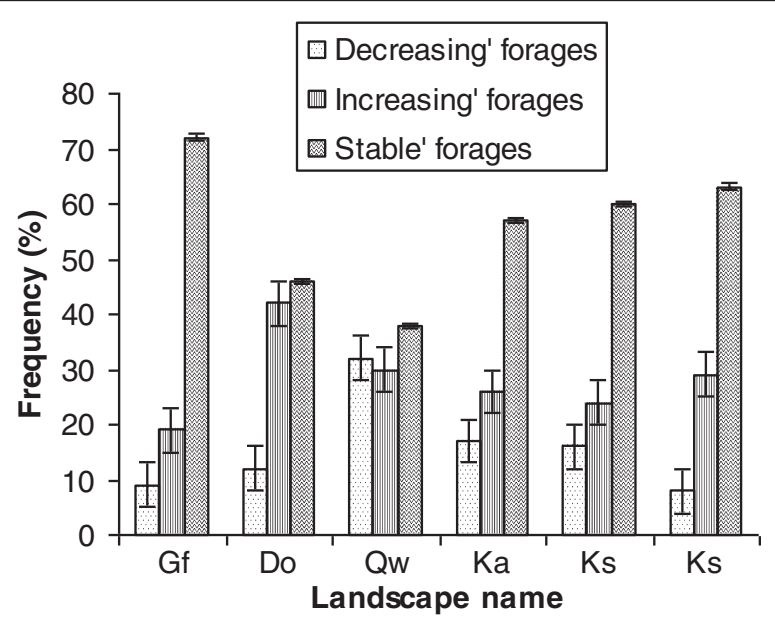

Figure 1 Frequency (\%) of 'decreasing', 'increasing' and 'stable' forages in the micro landscapes of Marsabit central area, northern Kenya (GF $=$ Gar foqolcha, Do = Diid ogono, $Q w=Q a a$ wachu, $K a=$ Kooticha ammessa, $K s=$ Kooticha sapansa, $K f=$ Kooticha fullessa). 


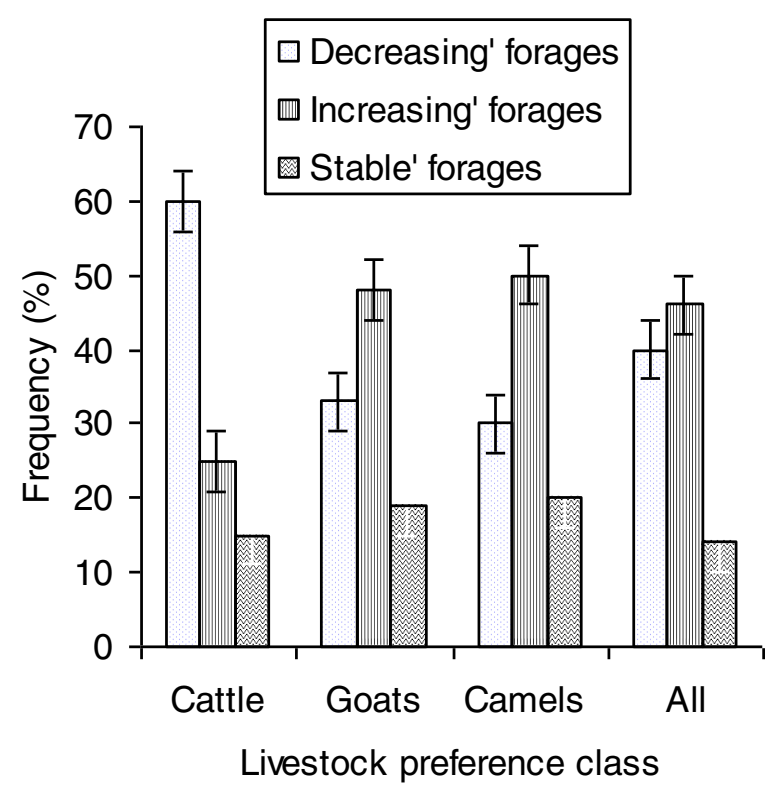

Figure 2 Frequency (\%) of 'decreasing', 'increasing' and 'stable' forages against different livestock preference classes in Marsabit central area of northern Kenya.

rangeland condition as indicated by replacement of preferred forages by less preferred forages. Landscapes with more 'increasing' forage species with less preference to livestock were assumed to be degraded (Tefera et al. 2007). The rangeland quality trend, however, seems to favour camels and goats husbandry in the study area, due to an increase in the abundance of browse plants, while the grasses needed by cattle are decreasing. A similar trend in the rangeland quality has also been reported in South West Marsabit of Kenya (Lusigi 1984) and Borana region of southern Ethiopia (GemedoDalle et al. 2005).

The informants were able to recall landscape vegetation changes from their personal experiences dating back to their childhood. Their historical oral narration captured continuous processes of environmental changes caused by various socio-economic factors, which included settlement, farming, charcoal burning and commercial logging. The knowledge of herders further provided an holistic approach to rangeland assessment and monitoring, where landscape vegetation was related to livestock productivity performance, suggesting that herders' knowledge is vital in rangeland condition monitoring and assessment (Allsopp et al. 2007; Roba and Oba 2008, 2009a; Verlinden and Dayot 2005).

From the evidence, it can be deduced that Borana herders' indigenous knowledge of rangeland quality assessment and monitoring is comparable to those used by other pastoralists in similar environments such as southern Ethiopia (Oba and Kotile 2001), Tanzania (Mapinduzi et al. 2003; Oba and Kaitira 2006), northern Namibia (Sheuyange et al. 2005), north central Namibia (Verlinden and Dayot 2005), Mongolia (FernandezGimenez 2000) and Arial pastoralists of northern Kenya (Roba and Oba 2009b). The indigenous knowledge is not only helpful in understanding the actual rangeland condition, but may also encourage local participation for rangeland rehabilitation activities (Robertson and McGee 2003). 


\section{Conclusions}

In pastoral areas where rangeland quality status has been deteriorating mainly due to combined forces of land use changes and increased livestock grazing, participatory rangeland quality assessment and monitoring with local herders has an important role in assessing rangeland degradation. In this study, Borana herders were able to describe landscape and context-specific qualitative changes in vegetation. The fact that the changes in forage composition have direct effects on livestock productivity performance is an important consideration in rangeland quality assessment and monitoring. The herders' personal experiences and collective social memory help in understanding rangeland quality trend and causative socio-economic events. The knowledge of Borana herders has thus shown that rangeland quality is a dynamic process of environmental changes which cannot be understood with one-time ecological assessments. Herders' knowledge can play a complementary role to the conventional ecological research methods of rangeland quality assessment and monitoring, and this knowledge may provide a basis for encouraging local communities in range rehabilitation.

\section{End notes}

${ }^{a}$ The system is practiced in southern Ethiopia. In northern Kenya, it is less visible, and only some activities associated with the gada cycles are observed. However, the Borana whether in southern Ethiopia or northern Kenya follow the reign of gada leaders ( $A b a$ gada), and this is very useful in recalling events that happened many years ago.

Competing interests

The authors declare that they have no competing interests.

\section{Authors' contributions}

BHD carried out field data collection, data analysis and drafting of manuscript. OG and HGR supervised field work and made comments on the manuscript. All authors read and approved the final manuscript.

\section{Acknowledgements \\ The authors acknowledge contributions to the field survey by Diba Guyo of KARI (Kenya Agricultural Research Institute) Marsabit and herders Bante Hallo, Jillo Jattani and Golich Boru. The authors also acknowledge the grant support by the Norwegian Research Council (NFR) under the project "Community Participation in the Implementation of the Global Environmental Conventions" (Project no. 161359/S39).}

\section{Author details}

${ }^{1}$ Kenya Agricultural Research Institute, P.O. Box 147, Marsabit, Kenya. ${ }^{2}$ Noragric, Department of International Environment and Development studies, Norwegian University of Life sciences, P.O. Box 5003, 1432, Norway. ${ }^{3}$ National Museum of Kenya, P.O. Box 40658, 00100, Nairobi, Kenya.

Received: 9 August 2011 Accepted: 13 February 2012

Published: 3 May 2012

\section{References}

Allsopp, N, C. Laurent, L. Debeaudoin, and M. Samuels. 2007. Environmental perceptions and practices of livestock keepers on the namaqualand commons challenge conventional rangeland management. $J$ Arid Environ 70: 740-754.

Berkes, F. 1999. Sacred ecology. Traditional ecological knowledge and resource management. USA: Taylor \& Francis.

Boeken, B, and M. Shachak. 1994. Desert plant communities in human-made patches-implications for management. Ecol App/ 4: 702-716.

Bollig, M, and A. Schulte. 1999. Environmental change and pastoral perceptions: degradation and indigenous knowledge in two African pastoral communities. Hum Ecol 27(3): 493-514.

Bowman, D.M. 2002. People and rangeland biodiversity. In Global rangelands. Progress and prospects, ed. A.C. Grice and K.C. Hodgikinson. Oxon: CAB International.

Bulle, H, M. Mamo, P. Geikuku, D. Golicha, M. Ngutu, S. Obanyi, M. Muya, and S. Amboga. 2010. Comparative evaluation of chloris, eragrostis and cenchrus grasses in Marsabit central District, northern Kenya. East African Agricul Forestry $J$ 76(1): 37-41.

Byakagaba, P. 2005. The Banyarwanda pastoralists herder knowledge of range management in Kiboga District, Uganda Msc thesis, Noragric. Norwegian University of Life sciences (submitted: Department of International Environmental and Development Studies. 
Darkoh, M.B. 2002. Regional perspectives on agriculture and biodiversity in the drylands of Africa. J Arid Environ 53: $261-279$.

Fernandez-Gimenez, M.E. 2000. The role of mongolian nomadic pastoralists' ecological knowledge in rangeland management. Ecol Appl 5: 1318-1326.

Gemedo-Dalle, T, B. Maass, and J. Isselstein. 2005. Plant biodiversity and ethnobotany of Borana pastoralists in Southern Oromia, Ethiopia. Economic Botany 1: 43-65.

Legesse, A. 1973. Gada: three approaches to the study of African Society. New York: The Free Press.

Lusigi, W.J. 1984. Integrated resource assessment and management plan for Western District, Marsabit, Kenya. IPAL Technical Report Number A-6. Nairobi: UNESCO.

Mapinduzi, A, G. Oba, R.O. Weladji, and J.E. Colman. 2003. Use of indigenous ecological knowledge of the Maasi pastoralists for assessing rangeland biodiversity in Tanzania. Africa J Ecol 41: 329-336.

Mauro, F, and P. Hardison. 2000. Traditional knowledge of indigenous and local communities: international debate and policy initiatives. Ecol Appl 5: 1263-1269.

Niamir-Fuller, M, and M. Turner. 1999. A review of recent literature on pastoralism and transhumance in Africa. In Managing mobility in African rangeland. The legitimization of transhumance, ed. M. Niamir-Fuller. London: Intermediate Technology Publications.

Oba, G, and L. Kaitira. 2006. Herder knowledge of landscape assessments in arid rangelands in northern Tanzania. J Arid Environ 66: 168-186.

Oba, G, and D. Kotile. 2001. Assessments of landscape level degradation in southern Ethiopia: pastoralists versus ecologists. Land Degradation Develop 12: 461-475.

Oba, G, E. Post, P. Syvertsen, and N. Stenseth. 2000. Bush cover and range condition assessments in relation to landscape and grazing in southern Ethiopia. Landsc Ecol 15: 535-546.

Oba, G. 1994. The role of indigenous range management knowledge for desertification control in Northern Kenya. Research Report No. 4. Linkoping University: EPOS.

Oba, G. 1985. Perception of environment among kenyan pastoralists: implications for development. Nomadic Peoples 19: 33-57.

Peden, M. 2005. Tackling 'the most avoided issue': Communal rangeland management in KwaZulu-Natal, South Africa. African J Range \& Forage Sci 22: 167-175.

Rodriguez, J. 2003. Challenges and opportunities for surveying and monitoring tropical biodiversity: a response to Danielsen et al. Oryx 37: 411.

Reed, M, and A. Dougill. 2002. Participatory selection process for indicators of rangeland condition in the Kalahari. The Geograph J 168(3): 224-234.

Roba, H, and G. Oba. 2009a. Efficacy of integrating herder knowledge and ecological methods for monitoring rangeland degradation in northern Kenya. Hum Ecol 37: 589-612.

Roba, H, and G. Oba. 2009b. Community participatory landscape classification and biodiversity assessment and monitoring of grazing lands in northern Kenya. J Environ Manage 90: 673-682.

Roba, H, and G. Oba. 2008. Integration of herder knowledge and ecological methods for land degradation assessment around sedentary settlements in sub-humid zone in northern Kenya. Int I Sustain Develop \& World Ecol 15: 251-264.

Robertson, H, and T. McGee. 2003. Applying local knowledge: the contribution of oral history to wetland rehabilitation at Kanyapella Basin, Australia. J Environ Manage 60: 275-287.

Scholes, R, and R. Archer. 1997. Tree-grass interactions in Savannas. Annu Rev Ecol Syst 28: 517-544.

Scoones, I. 1999. Ecological dynamics and grazing resource tenure: A case study from Zimbabwe. In Managing mobility in Africa rangeland. The legitimization of transhumance, ed. M. Niamir-Fuller. London: Intermediate Technology Publications Ltd.

Sheuyange, A, G. Oba, and R. Weladji. 2005. Effects of anthropogenic fire history on Savanna vegetation in northeastern Namibia. J Environ Manage 75: 189-198.

Shibia, M. 2010. Determinants of attitudes and perceptions on resource use and management of marsabit national reserve, Kenya. J Human Ecol 30: 55-62.

Tefera, S, B. Dlamini, A. Dlamini, and V. Mlambo. 2007. Current range condition in relation to land management systems in semi-arid savannas of Swaziland. Afr J Ecol 46: 158-167.

Verlinden, A., and B. Dayot. 2005. A comparison between indigenous environmental knowledge and a convectional vegetation analysis in north central Namibia. J Arid Environ 62: 143-147.

Vetter, S, W.M. Godwan, W.J. Bond, and W.W. Trollope. 2006. Effects of land tenure, geology and topography on vegetation and soils of two grassland types in South Africa. African J Range \& Forage Sci 23(1): 13-27.

Warui, M, and I. Nduma. 2001. Sustaining the voices of pastoralists and agro-pastoralists on Marsabit Mountain: A drought refuge in northern Kenya. In APSK Annual Symposium Proceedings, March 7-8, 2001. Njoro Kenya: Egerton University.

Yoccoz, N, J. Nicholas, and T. Boulinear. 2001. Monitoring of biological diversity in space and time. Trends Ecol Evol 15: 446-453.

doi:10.1186/2041-7136-2-2

Cite this article as: Dabasso et al: Livestock-based knowledge of rangeland quality assessment and monitoring at

landscape level among borana herders of northern Kenya. Pastoralism: Research, Policy and Practice 2012 2:2. 